\title{
An Inquiry into the Meaning of Possession and Control over Financial Assets and the Effects on Third Parties
}

\author{
Elena Christine Zaccaria*
}

\section{Keywords}

Financial collateral; perfection; security interest; possession and control.

\begin{abstract}
Following the implementation in the United Kingdom of the Directive on financial collateral arrangements 2002/47/EC, it is extremely difficult - if not simply impossible - to confine certain concepts of law (mainly those of possession and control) within sharp and definitive boundaries. Nowadays, the main perception is that there can be different forms of control as well as different forms of possession (depending on the type of asset involved and/ or the terms and conditions posed by the parties to the security agreement). The article suggests that this 'flexibility' is by no means surprising as it reflects the tradition, ingrained in English law to continuously stretch the notion of property to accommodate market needs.
\end{abstract}

\section{A. Introduction}

The purpose of this article is to analyse the concepts of control and possession as methods of perfection of a security interest over financial assets, an issue that has given rise to considerable discussion among practitioners (but not to the same extent among academics ${ }^{1}$ ).

The word 'perfection'2 is used to describe the various means by which a secured creditor can make his/her security interest effective against third parties ${ }^{3}$. As a general rule, in order to obtain perfection, 'the law usually requires [...] the performance of some act which puts third parties on notice of the security interest'. ${ }^{4}$ In the United Kingdom, the most important method of perfection is achieved through registration of the security interest in a public record whose main function is to inform the interested parties of the existence of charges on the debtor's assets. ${ }^{5}$

\footnotetext{
* Guest Lecturer, Department of Law, London School of Economics and Political Science. The author is grateful to Professor Micheal Bridge for his valuable comments on the drafts of this article. The author would also like to thank Joanna Benjamin, Hugh Beale, Emma Chell, Roy Goode, Louise Gullifer, Eva Micheler, Habib Motani, Philip Paech and Babette Pragnell for having taken the time to share their valuable experience and give their answers to all the author's many questions. Any errors are the author's own.

1 See, however, the extensive and detailed analysis offered by H. Beale "Financial Collateral" in H. Beale and others, The Law of Security and Title-Based Financing (2nd edn, OUP 2012), at para. 3.47 and L. Gullifer, "What Should We Do about Financial Collateral?" (2012) 65 (1) Current Legal Problems, at 377.

2 The concept of 'perfection' was originally coined in Article 9 of the Uniform Commercial Code (hereafter 'UCC' $)^{2}$ and then gradually gained acceptance outside the United States.

3 This means that failure to comply with the perfection requirements renders the security interest void in the debtor's insolvency. Perfection is not a condition of validity of the security interest, but it is essentially designed to ensure that third parties are given notice of the existence of encumbrances on assets. See L. Gullifer, Goode on Legal Problems of Credit and Security (5 ${ }^{\text {th }}$ edn, Sweet \& Maxwell 2013) at para. at para. 2-16 and E. McKendrick, Goode on Commercial Law (4 ${ }^{\text {th }}$ edn, Lexis-Nexis 2009), at 689-719.

${ }^{4}$ E. McKendrick, supra n. 3 above, at 689.

5 Therefore, the duty to register can be described as reflecting 'the law's dislike of the secret security interest, which leaves the debtor's property apparently unencumbered,' R. Goode, Principles of Corporate Insolvency Law, (4 $4^{\text {th }}$ edn, Sweet \& Maxwell 2011), at 608. See also M. G. Bridge, "The Scope and Limits of Security Interests" [2008] ECFR - Special Volume: The Future of Secured Credit in Europe, 180 and J. Simpson and F. Dahan, "Publicity of Security Rights: Why and How" (2005) 1 JIBFL, 3.
} 
In 2002 the Directive on financial collateral arrangements 2002/47/EC (hereafter 'FCD') ${ }^{6}$ was introduced to recognise, for certain forms of investment property the transfer of 'control' and 'possession' as a method of perfection alternative to registration. ${ }^{7}$ But what exactly is meant by the terms 'possession' and 'control'?

The concept of possession does not seem (at least at first glance) to warrant further investigation - being a well developed principle of English property law, traditionally confined to the idea of an exclusive and absolute dominium over tangible assets. The main point is that if the creditor has possession there is no need for registration, as possession is able to provide sufficient notice of the existence of the charge to the outside world. ${ }^{8}$

Concerns, however, can be raised when trying to establish the meaning of control, as this is a completely new concept for English law.

One way to think of control is to regard it as the 'intangible's equivalent to possession of tangibles'. This means that control can fulfil the same purpose as possession (i.e. excluding others from having control over the asset and consequently putting third parties on notice of the charge) but merely for intangibles ${ }^{10}$. This approach may have many compelling points, yet it does not seem to have been strictly accepted in the United Kingdom. Hence, the next step of this discussion is to seek plausible answers to the following questions: (i) what is the precise meaning of control? (ii) does the FCD provide a clear definition of this new concept? (iii) what is the solution adopted in the UK? (iv) does the new method of perfection (envisaged for financial collateral arrangements) offer sufficient notice to third parties? ${ }^{11}$

The article intends to evaluate from a theoretical perspective the nature of control and possession, in an attempt to identify their key features and determine how these concepts can be accommodated into the existing legal framework. More specifically, it will

${ }^{6}$ Directive 2002/47/EC (on Financial Collateral Arrangements) as amended by Directive 2009/44/EC of May 6, 2009. Financial collateral arrangements are typically divided in two categories, title transfer financial arrangements (e.g. repurchase agreements) and security financial collateral arrangements (e.g. pledges, liens, mortgages or charges).

7 One of the main purposes of the FCD and the implementing of regulations is to remove the formal requirements in the creation and perfection of a financial collateral arrangement' (Article 3.1 FCD). The aim of this provision is to reduce formalities, cut costs and prevent delays when transferring investment securities.

${ }^{8}$ E. McKendrick, supra n. 3, at 689. See also L. Gullifer, Goode on Legal Problems of Credit, supra n. 3, at para. $2-20$.

9 J. J. White and R. S. Summers, Uniform Commercial Code: Secured Transactions (Hornbook Series, 2000) at 775.

${ }^{10}$ The main point is that a security interest in intangibles cannot be perfected by possession when 'there is no indispensable res to be possessed (like a negotiable instrument)', Id. Nevertheless, 'some of these intangibles interests can be put under the control of a secured creditor to the exclusion of others, and this will put third parties on notice.', $I d$. This means that for certain forms of intangible property the registration requirement (as a substitute to possession) may be deemed unnecessary as control seems to provide notice of the security interest to third parties. See also M. G. Bridge, "The Law Commission's Proposals for the Reform of Corporate Security Interests" in J. Getzler and J. Payne (eds.) Company Charges: Spectrum and Beyond (OUP 2006) at 268 who states that control should be "to certain forms of intangible property what possession is to tangible property.'

11 Over the past fourteen years several attempts have been made in the United Kingdom to answer these questions but despite these efforts, certain aspects of uncertainty have remained unresolved. A clarification on these points is now, more than ever, necessary in view of the new EU regulatory framework in the area of derivatives markets, which will most likely lead to an increase in the use of financial collateral arrangements. Security financial collateral arrangements are considered critical to the liquidity of the financial markets and to financial stability. The Financial Market Law Committee ("FMLC") has recently argued that the volume of these types of transactions is likely to increase as a result of the regulatory changes brought about by Regulation (EU) No. 648/2012 ("EMIR"). See on this point FMLC, Meaning of "possession", "control" and "excess financial collateral" under the Financial Collateral Arrangements (No. 2) Regulations 2003, 13 April 2015 (hereafter 'FMLC 2015'), at para. 5. 
endeavour to respond to the four questions listed above and overall will demonstrate that the implementation of the FCD in the United Kingdom must lead us to reconsider the traditional perception of certain principles of property law, mainly those of possession and publicity.

The argument presented here is that possession can no longer be defined in terms of an absolute dominium over material things, as nowadays such a concept can also be extended to intangibles and does not necessarily imply a form of 'exclusive' control over the asset. Similarly, the concept of publicity (typically associated to the perfection of a security interest) does not have to provide stricto sensu notice to the world at large, as there may be circumstances in which such notice is not 'public' (being limited to certain categories of third parties) and where the existence of a security interest is not even visible (meaning that the information on a charge can only be obtained through an intermediary).

This occurrence is not at all surprising, however, as it confirms the distinctive feature of English property law and its ability to adapt and address market needs by frequently stretching and repositioning the boundaries of well-established principles rather than creating exceptions or novel concepts of law.

The analysis takes into consideration particular types of financial assets which are covered by the FCD, i.e. indirectly held securities. The expression indirectly held securities' refers to assets that are held by investors indirectly, i.e. through one or more intermediaries (such as financial institutions, brokers, depositories and other professional investors). ${ }^{12}$ The use of these types of assets usually involves an electronic system, whereby the interest of the investor is represented by a credit entry to his/her securities account ${ }^{13}$ and transfers of securities are made in the same way as bank funds transfer (i.e. by debit and credit entries to such accounts). ${ }^{14}$ Both the widespread use, in market practice, of these types of assets and the complexity of their structure makes them a very interesting platform for evaluating the meanings of control and possession as methods of perfection of a security interest.

\section{B. The compound meaning of control}

It is possible to identify different types of control, according to two main sets of distinctions. ${ }^{15}$ Firstly, control may be either positive or negative: 'positive control is the ability to remove an asset from the collateral pool and negative control is the ability to

\footnotetext{
12 The central point of this practice is that investors may be separated from the issuer of the underlying securities by multiple layers of intermediaries (often spanning a number of jurisdictions). This means that, in a very simplified scenario, an intermediary in the highest tier of the holding chain (typically a central securities depository - CSD, but not necessarily in all jurisdictions) holds for a second-tier intermediary, the second-tier intermediary holds for a third-tier intermediary and so on down the chain to the ultimate investor.

13 Nowadays, securities are issued and transferred by means of intangible electronic records rather than paper certificates, as was once the norm. Starting from the early 1970s in the United States and the 1980s in the United Kingdom, the physical delivery of paper documents was largely replaced by electronic settlement, which involves a technique called 'book-entry transfer'. For an analysis of this practice see, among others, J. Benjamin, Interest in Securities. A Property Law Analysis of the International Securities Markets (OUP 2000, at 3 - 59 and M. Yates and G. Montagu (4th edn, Tottel Publishing, 2013), at 1 - 39.

${ }^{14}$ Consistently with this practice, the credit of securities to the account held by an intermediary confers on the investor the right both to dispose of the securities and to receive the corporate and economic benefits attached to the financial assets.

${ }^{15}$ H. Beale "Financial Collateral" in H. Beale and others, supra n. 1, at paras. 3.33 - 3.43. On this point see also J. Benjamin, Financial Law (OUP 2007) at para. 20.117 - n. 192; J. Benjamin, "Securities Collateral" in J. de Lacy (ed.), The Reform of UK Personal Property Security Law Comparative Perspectives (Routledge - Cavendish 2009) at 258 - 259 and A. Zacaroli, "Taking Security over Intermediated Securities: Chapter V of the Unidroit (Geneva) Convention on Intermediated Securities in over Intermediated Securities" in L. Gullifer \& J. Payne (eds.), Intermediated Securities. Legal Problems and Practical Issues (Hart Publishing 2010) at 184.
} 
prevent an asset from being so removed'. ${ }^{16}$ Secondly, 'either positive or negative control may be legal (i.e., the right to remove or prevent removal as the case may be) or operational (i.e., the practical ability to remove or prevent removal, by account entry or otherwise). ${ }^{17}$ In other words, legal control is the 'right' of the secured party to dispose (positive control) or to prevent disposal (negative control) of the collateral and is achieved by way of a contractual agreement between the debtor and the secured creditor. Alternatively or cumulatively, operational control is the 'practical ability' of the secured party to 'control' the delivery of the assets. This situation typically occurs when the debtor and the secured creditor agree to transfer the collateral into the account of the secured party (rather than leaving the securities credited in the debtor's account). By doing so, the secured party is in a practical (de facto) position to either dispose of the securities (positive control) or prevent any other person from dealing with those assets (negative control). Operational or practical control may be acquired by the secured party, despite the concomitant existence of a legal control over the collateral. This means that the secured party may have a practical ability to 'remove or prevent removal' ${ }^{18}$ of the collateral from the account, 'whether or not in doing so it would be in breach of its contractual obligations to the debtor.' ${ }^{19}$

This interpretation of the notion of control shows that in the practice of indirectly held securities it is possible to identify multiple forms of control, whose content is liable to change significantly according to the circumstances: control may be positive and/or negative as well as operational and/or legal. This means that (consistent with the concept of property) the notion of control is composed of 'building bricks, which can be used and put together in different ways. ${ }^{20}$

The core idea is that there is no absolute or single definition of control because this concept comprises different features that can be combined in a number of ways depending on the intention of the parties. Indeed, a closer look at the practice of indirectly held securities shows that parties may choose from at least seven different combinations. $^{21}$

\section{Practical, legal, negative and positive control}

The first combination comprises all four types of control, i.e. legal and practical control as well as positive and negative. This particular situation is the 'safest' way of creating a security interest over the collateral and it consists both of (i) transferring the securities into an account 'controlled' by the secured creditor and of (ii) conferring to such party the contractual right to dispose, and to prevent any other person from disposing, of the collateral. Even though it confers the maximum degree of control to the creditor, in practice this combination is likely to be preferred in full-title transactions.

\footnotetext{
${ }^{16}$ J. Benjamin, Financial Law, supra n. 15, at para. 20.117.

${ }^{17}$ Ibid.

18 Ibid., at para. 20.117. See also H. Beale, "Perfection of Security Interests Over Financial Collateral" in H. Beale and others, The Law of Personal Property Security (OUP 2007), at paras 10.18 - 10-35 and L. Gullifer, Goode on Legal Problems of Credit, supra n. 3, at paras. 4-22 and 6-32.

${ }^{19}$ FMLC, Issue 87 Control Gray v. G-T-P Group Ltd, December 2010 (hereafter 'FMLC 2010'), para. 6.10. In other words, in this case there is a need to obtain some form of action by the creditor in order to remove the collateral from the account (notwithstanding the debtor's contractual right to dispose of the collateral). 20 The expression was originally coined with regard to the traditional proprietary rights of enjoyment, alienation and possession. In other words, it referred to the 'bundle of rights' that may be exercised by the rightful owner or possessor with respect to a 'thing'. On this point see A. P. Bell, Modern Law of Personal Property in England and Ireland (Butterworths 1989) at 5. The main objective of using this expression was to highlight the fact that the same bundle of rights is not necessarily attached to all forms of property. This 'flexible' idea of property can also be detected when analysing the concept of control.

21 The author is grateful to Habit Motani and Emma Chell for describing these different combinations.
} 


\section{Practical, negative and positive control}

The second combination is acquired when the collateral is transferred into the creditor's account but the debtor maintains the right to remove the collateral at any time prior to enforcement. In this case, the creditor is in a 'de facto' (but not legal) position to sell or transfer the collateral and to prevent the debtor from exercising his/her contractual rights over the collateral. ${ }^{22}$

\section{Practical, legal and positive control}

The third combination comprises three types of control, i.e. practical, legal and positive. In practice, this means that the collateral is transferred to the account of the secured party who has also acquired a contractual right to sell or transfer these assets without further consent from the debtor.

\section{Practical, legal and negative control}

Consistent with the third combination, in this fourth case the secured party enjoys both practical and legal control. The main difference between these two combinations is that in the latter case, unlike in the former, the secured party has a contractual right to prevent the debtor from dealing with the charged assets (negative control) rather than a right to dispose of the collateral (positive control).

\section{Legal and positive control}

Legal and negative control

Legal, positive and negative control

Each of the last three combinations is characterised by the fact that the collateral is left credited on the debtor's account. Thus, in these cases the secured party only remains in a legal position (and not a practical one) to dispose of the collateral (legal and positive control'), to prevent others from disposing of such assets ('legal and negative control') or to exercise both options ('legal, positive and negative').

The number of these different forms of control is increased even further owing to the existence of multiple degrees of legal control, whether positive or negative. For example, in cases of negative control, the debtor may undergo an absolute preclusion from dealing with the collateral or, alternatively, be restricted to exercising only limited rights (such as the right of substitution or to withdraw excess financial collateral). ${ }^{23}$ Similarly, in cases of positive control the secured creditor may obtain either unlimited or more restricted rights to sell or transfer the collateral. ${ }^{24}$

These examples provide further evidence of the compound nature of control, in terms of the creditor's ability to exclude others from using and enjoying the collateral. A careful analysis of the functioning of this new concept has shown that it is generally possible to identify multiple forms of control, where the content may vary significantly. Hence, one

\footnotetext{
22 With this type of combination, the debtor is not in a position to automatically access those securities, without the practical [emphasis added] involvement of the creditor (or of a person acting on the creditor's behalf). For an example of this scenario, see the case Gray v. G-T-P Group Ltd [2010] EWHC 1772 (Ch). ${ }^{23}$ See infra text to nn. $28-29$.

${ }^{24}$ Moreover, in the case of negative control the debtor's right of disposal may be subject either to prior authorisation by the creditor for each transaction or, alternatively, to a general authorisation released at the time of creating a security interest.
} 
of the main issues is to establish which of these forms of control is envisaged under the FCD.

\section{The uneasy case for understanding the meaning of 'control' under the FCD}

The $\mathrm{FCD}^{25}$ does not define what constitutes 'control' and this uncertainty leaves ample room for debate. ${ }^{26}$ Initially the discussion was focused primarily on the first set of distinctions, in an attempt to understand whether EU law contemplates negative control, positive control or both. The wording seems to suggest that 'negative control' alone is probably sufficient to satisfy the perfection requirement, while 'positive control' alone is not. ${ }^{27}$ This interpretation relies on Recital 10 in the Preamble to the FCD, which states that the directive covers 'only those financial collateral arrangements, which provide for some form of dispossession'.

The rationale behind the dispossession requirement is to prevent the debtor from having control of the assets and hence from transferring or delivering them to third parties. If the debtor retains the ability to deal with the financial collateral, it cannot be considered as dispossessed. ${ }^{28}$

The last sentence of Article 2(2) of the FCD seems to confirm this analysis when it specifies that any right of the debtor to substitute financial collateral or withdraw excess financial collateral shall not prevent the secured creditor from being in possession or having control of the assets. If the intention under the FCD were to contemplate the possibility of the debtor's disposing of the collateral this provision would be unnecessary, as the right of substitution or the possibility to withdraw excess financial collateral should be included in the debtor's retention of the right to trade the financial collateral. Thus, the clarification under Article 2(2) would be superfluous for cases in which the debtor had such a power and 'one would expect there to be some reference to that, but there is none?. ${ }^{29}$

\footnotetext{
${ }^{25}$ In June 2009, the EC Directive 2009/44 'amending Directive 98/26/EC on settlement finality in payment and securities settlement systems and Directive 2002/47/EC on financial collateral arrangements as regards linked systems and credit claims' was officially published in the EU Official Journal ('EC Directive $2009 / 44^{\prime}$ ). With respect to financial collateral arrangements the objective was to expand the number of financial claims which can be collateralised. The main amendment to the FCD is the inclusion of credit claims eligible for the collateralisation of central bank credit operations, which are defined as 'pecuniary claims arising out of an agreement whereby a credit institution [...] grants credit in the form of a loan.'

26 The literature on the meaning of control under the FCD has been quite productive. For an analysis see, for example, S. Goldsworthy, "Taking possession and control to excess: issues with financial collateral arrangements under English law" (2013) J.I.B.F.L. 71; E. Chell and others, "Possession and control: financial collateral remains a Gray area" (2013) 1 JIBFL 43; D. Saoul, "Lehman: liens untied" (2013) JIBFL 3, 143; L. Gullifer, "What should we do about financial collateral?", supra n. 1, 377; D. Turing, "New Growth In The Financial Collateral Garden" (2005) 1 JIBFL 4; R. McCormick, "EU Directive on Financial Collateral Arrangements: Replies of a Working Group of the CLLS Financial Law Committee to the Questionnaire of February 2006 to the Private Sector From the European Commission for the Drafting of the Evaluation Report" (2006) 6 JIBFL 263; A. Fawcett, "The Financial Collateral Directive: an examination of some practical problems following its implementation in the UK" (2005) JIBLR 95 and H. Beale, "Reform of the Law of Security - Another View" (2004) 4 JIBFL 117.

27 See on this point English Law Commission Company Security Interests, Report No 296, 2005 (hereafter 'English Law Commission (2005)'), at paras 5.46 - 5.50 and L. Gullifer, Goode on Legal Problems of Credit, supra n. 3 at para. 6-35.

${ }^{28}$ On this point, see English Law Commission (2005), paras. 5.52 - 5.54; L. Gullifer, Goode on Legal Problems of Credit, supra n. 3 at para. 6-35.

${ }^{29}$ English Law Commission (2005), at para 5.54. There is also another provision in the FCD that is often mentioned to confirm this approach, i.e. the provision on enforcement (Art. 4 (1) FCD. For an analysis see H. Beale, "Perfection of Security Interests Over Financial Collateral" in H. Beale and others., The Law of Personal Property Security, supra n. 18 at para. 10-31. See also English Law Commission (2005) at paras. 5.54 -5.55 .
} 
This interpretation has recently been confirmed by the Court of Justice of the European Union ('CJEU') in its first (and only) ruling on the notion of control and possession under the FCD. More specifically, in its decision of November 2016 the CJEU confirms the idea that the test of 'possession' and 'control' of the secured creditor under Article 2(2) of the FCD is satisfied only in those circumstances where the debtor is deprived of the ability to dispose of the financial collateral ${ }^{30}$. This situation occurs when the secured creditor has either negative control alone, or both negative and positive control, but it does not allow for what is usually called 'positive control without negative control'.

The approach that appears to be adopted by the FCD is not in line with US law, which was the first legal system to introduce, under Article 9 of Uniform Commercial Code (hereafter 'UCC') - in connection with the 1994 revision to Article 8 UCC regarding investment property - the concept of control as a method of perfection of a security interest. Indeed, the idea set out under revised Article $8 \mathrm{UCC}$, is that 'positive control' alone may be sufficient to perfect a security interest. More specifically, in Comment 7 to \8-106 UCC, the Drafting Committee for the revision to Article 8 argues that the key to the control concept is the ability of the purchaser or the secured creditor to have the securities sold or transferred without further action by the owner. ${ }^{31}$ In particular, under certain circumstances there is no requirement that the powers held by the purchaser or the secured creditor be exclusive, as the owner may have concomitant rights to substitute, to receive dividends and distributions, as well as to trade those securities. ${ }^{32}$

Unlike Article 8 UCC, the FCD does not provide guidelines clarifying what amounts to 'control', although the leading opinion among academics and practitioners is to interpret the wording of the directive in the negative (rather than positive) sense. ${ }^{33}$

With respect to the second set of distinctions, the FCD does not provide clear answers as to whether it includes situations of practical control and/or legal control. The wording in the directive suggests that a combination of 'legal control' and 'practical control' can indeed satisfy the perfection requirement, while 'practical control' alone is not sufficient. This interpretation relies on Article 2(2) of the FCD which prevents the debtor from retaining a general right [emphasis added] to trade the charged assets (with the exception of a right of substitution or withdrawal of excess collateral). Such a limitation on the debtor's right [emphasis added] to dispose of the asset is inconsistent with a scenario where the collateral is transferred into the creditor's account but the debtor retains the right [emphasis added] to remove the collateral at any time prior to enforcement (i.e. practical control without legal control). ${ }^{34}$

A more difficult aspect to establish is whether legal control alone can be considered sufficient to satisfy the perfection requirement. There seem to be different views on this point $^{35}$, given that the wording of the FCD has proven (once again) to be somewhat

\footnotetext{
30 Private Equity Insurance Group SIA v Swedbank AS [2016] EUECJ C-156/15 (10 November 2016).

31 Official Comment $\int 8-106$ UCC at para. 7.

32 \ 8-106 (f) UCC.

33 See among others see H. Beale "Financial Collateral" in H. Beale and others, supra n. 1 at para. 3.47.

34 This has recently been confirmed in the Opinion of Advocate General Szpunar delivered on 21 July 2016 in relation to case C-156/15 Private Equity Insurance Group SLA v Swedbank AS at para. 51. See on this point also Gray v. G-T-P Group Ltd, EWHC 1772 (Ch) at para. 54 and Re Lehman Brothers International (Europe) (In Administration) [2012] EWHC 2997 (Ch), at para. 131. Unlike the FCD, Article 8 UCC does include practical control alone, S. L. Harris and C. W. Mooney, Security Interest in Personal Property. Cases, Problems and Materials (4th edn, Foundation Press 2006), at 435.

${ }^{35}$ L. Gullifer, Goode on Legal Problems of Credit, supra n. 3 at para. 6-36.
} 
arduous to interpret and the recent CJEU pronouncement is unfortunately silent on this point ${ }^{36}$.

Several years have passed since the entry into force of the FCD within the European Union but doubts still remain concerning the different forms of control that can be used in the case of perfection. The discussion so far seems to suggest that at least two combinations of control should fall within the scope of the FCD and that three are certainly to be excluded. The combinations that are accepted under the FCD consist of (i) practical, legal, negative and positive control and (ii) practical, legal and negative control. On the other hand, those forms that do not seem to be consistent with the wording of the Directive are (iii) practical, negative and positive control, (iv) practical, legal and positive control and (v) legal and positive control.

The problem still exists for the last two combinations, given that there is no explicit indication in the Directive as to whether (vi) legal and negative control and (vii) legal, positive and negative control are considered valid methods of perfection of a security interest. These considerations make it necessary to determine whether English law has managed to cast light on this matter, by identifying which of the different forms of control can be applied in practice.

\section{The UK's approach on financial collateral arrangements}

The FCD was implemented in the United Kingdom with the 2003 Financial Collateral Arrangements (No. 2) Regulations (hereafter 'FCAR') and subsequently amended by the 2010 Financial Markets and Insolvency (Settlement Finality and Financial Collateral Arrangements) (Amendment) Regulations (hereafter 'FMIR'). Regulation 3 (2) of the FCAR offers a very restrictive interpretation of Article 2(2) of the $\mathrm{FCD}^{37}$. In particular, it states that perfection of a security interest can be achieved only in those cases where the 'financial collateral has been credited to an account in the name of the [secured creditor] or a person acting on his behalf [...] provided that any rights the [debtor] may have in relation to that financial collateral are limited to the right to substitute financial collateral of the same or greater value or to withdraw excess financial collateral'. ${ }^{38}$

This means that for the purposes of the FCAR the debtor is deprived of the power to dispose of the collateral, being admitted to exercise only exceptional interests, i.e. 'the right to substitute financial collateral of the same or greater value or to withdraw excess financial collateral'. ${ }^{39}$ The inclusion of these limited rights under Regulation 3 (2) of the FCAR was the result of the decision to comply with the FCD where it specifies that any right of substitution or withdrawal of excess financial collateral in favour of the debtor shall not prevent the secured creditor from being in possession or having control of the asset. $^{40}$

Looking at this provision, it could be argued at first glance that English law seems to accept only the first two combinations of control, i.e. practical, legal, negative and positive control as well as practical, legal and negative control. This initial perception, however, is partially misleading given that although Regulation 3 (2) of the FCAR contemplates the

\footnotetext{
${ }^{36}$ HM Treasury, Consultation Paper, Implementation of EU Directive 2009/44/EC on settlement finality and financial collateral arrangements, August 2010 (hereafter 'HM Treasury August 2010') at para. 3.3.

37 The FCAR was recently amended by the 2010 Financial Markets and Insolvency (Settlement Finality and Financial Collateral Arrangements) (Amendment) Regulations (hereafter 'FMIR'). The intention was primarily to implement the EC Directive 2009/44 within the United Kingdom so as to expand the FCD's scope of application to cover credit claims. However, the drafting of the FMIR was also an opportunity to overcome at least part of the uncertainties or the limitations concealed in the wording of the FCD.

${ }^{38}$ Reg. 3(2) FCAR

39 Ibid.

40 Art. 2(2) FCD.
} 
first two combinations as a valid method of perfection, it does not include them within the meaning of control but rather within the concept of possession. More specifically, it introduces a new definition of possession that applies specifically to investment securities and that includes the case where the financial collateral is transferred onto the creditor's account and the debtor is prevented from having unrestricted rights over the assets.

\section{D.1 The new concept of possession: a critical analysis}

The recognition of a new definition of possession seems to contradict the idea that 'possession has no meaning [...] as regards intangible property ${ }^{41}$ and that control should be considered as the 'intangible's equivalent to possession of tangibles'. ${ }^{2}$ Although the solution to apply the notion of possession to investment securities was warmly welcomed by most market players, ${ }^{43}$ it does not seem to be completely in line with the conventional way of interpreting this concept.

Prior to the introduction of the FCAR, it was widely accepted in English law that in the case of intangible personal property, possession is impossible'. ${ }^{44}$ The reason for this is that 'rights in these choses in action [as opposed to those in choses in possession] have to be asserted through the medium of legal action'. ${ }^{45}$ This is particularly emphasised by Lawson and Rudden, when they argue that ' $[\mathrm{t}]$ he rules governing the recovery of property vary with the nature of the property ${ }^{346}$ : '[s] ome kinds of property can be possessed, others cannot'. ${ }^{47}$

Regulation 3 (2) of the FCAR overrides these common law requirements by introducing a new idea of possession, which applies to investment securities. The issue was also addressed in Re Lebman Brothers International (Europe) (In Administration) which concerned the interpretation of the FCD and FCAR. In his decision, Briggs J. confirms the idea that 'it would be wrong to limit possession in such a way as to exclude any application to intangibles'. ${ }^{48}$

It is difficult to understand the reasons that lie behind this position. For the purposes of Art. 2(1) of the FCD, 'financial collateral' includes both bearer securities in certificated form (which are treated as tangibles) as well as securities in dematerialised form. Thus, there is no inconsistency with the scope of the directive in using the notion of possession for tangibles as well as for documentary intangibles and the notion of control for all other intangibles. If the intention in the directive is to apply the concept of possession to all types of collateral, what reason would there be to add the concept of control as a new method of perfection?

${ }^{41}$ Gray v. G-T-P Group Ltd, EWHC 1772 (Ch) at para. 54.

${ }^{42}$ J. J. White and R. S. Summers, supra n. 9 at 775. See supra text to nn. 8 and 10.

43 R. Parsons and M. Denning, "Financial collateral - an opportunity missed" (2010) 5 (3) May Law \& Fin. Mkt. Rev. 164. See also FMLC, Implementation of EU Directive 2009/44/EC on settlement finality and financial collateral arrangements, April 2011.

44 M. G. Bridge, Personal Property Law (3 ${ }^{\text {rd }}$ edn, OUP 2002) at 15 and 144. See also the $4^{\text {th }}$ and latest edition of this book at page 15. Recently, this principle has been confirmed in Your Response Ltd v. Datateam Business Media Ltd [2014] EWCA Civ. 281 where the Court of Appeal strengthens the idea that while 'possession is concerned with the physical control of tangible objects', 'practical control is a broader concept, capable of extending to intangible assets and to things which the law would not regard as property at all', ibid., para. 23. Interestingly, in this case no reference is made to Regulation 3 (2) of the FCAR.

45 Ibid. See also F. H. Lawson and B. Rudden, The Law of Property (2nd edn, OUP 1982) at 20 and M. G. Bridge, supra n. 44, at 15.

${ }^{46}$ F. H. Lawson and B. Rudden, supra n. 45 at 40.

${ }^{47}$ Ibid.

48 [2012] EWHC 2997 (Ch) at para. 131. 'Intangibles', Briggs continues, 'are, and were by the time the Directive was being prepared, the very stuff of modern financial collateral', ibid. For a different view on this point see Gray v. G-T-P Group Ltd, EWHC 1772 (Ch) at para. 54. 
The new idea of possession, which applies to all types of collateral (regardless of their nature) is consistent with the the Financial Market Law Committee (hereafter 'FMLC')'s view that 'possession of securities' should not refer exclusively to bearer securities in certificated form but should be extended to securities in dematerialised form. ${ }^{49}$

Although the FMLC makes a valuable comment where it states that nowadays bearer securities issued in the form of a paper instrument are rarely used in practice,${ }^{50}$ it does not provide a convincing argument for having to apply the notion of possession to all types of collateral. ${ }^{51}$

A more appropriate way to interpret the scope of the directive would be, in a sense, to allow EU Member States to choose between different options: either extend the meaning of possession to include intangible assets or introduce the concept of control which is specifically addressed to cover intangibles. Consistent with this reasoning, the scope of the directive is simply to set out a new method of perfection for financial collaterals, leaving the decision of naming it to the Member States.

The author believes this interpretation to be the most convincing for two main reasons. Firstly, if we look at the travaux préparatoires of the FCD it is clear that one of the major challenges faced by EU authorities during the negotiation process was to strike a balance between creating a uniform framework for financial collateral arrangements on the one hand, and minimising interference in the laws of Member States on the other ${ }^{52}$. Traditionally, property law has been one of the areas in which EU harmonisation has encountered the strongest resistance by Member States and therefore it is also where the differences among national laws remain significant. ${ }^{53}$ This explains why throughout the process of the drafting of a new (and more efficient) regime on financial collaterals, EU authorities have tried (as much as possible) to use 'neutral language', striving to avoid terminology or forms which are strictly linked to national legal systems. In this context, it is probably no coincidence that references to possession (which is one of the oldest and well established concepts of property law) did not appear in the earlier versions of the draft of the directive, as it was added together with 'control', at the very final stages of the legislative process ${ }^{54}$. The purpose of this amendment in the draft of the directive was not necessarily to impose on Member States the introduction of a new meaning of possession but simply to explain the exact steps that should be taken when perfecting a security

\footnotetext{
${ }^{49}$ FMLC 2010, para 4.8. According to the FMLC, 'the concept of possession has an "autonomous" meaning in EU law and it must be interpreted in accordance with the wording of the directive rather than with general principles of English law', ibid.

${ }^{50}$ See on this point also Re Lehman Brothers International (Europe) (In Administration) [2012] EWHC 2997 (Ch), at para. 131). This point has even greater value if we consider certain changes introduced in the UK by the Small Business, Enterprise and Employment Act 2015 which (as from May 2015) prohibits companies from using bearer shares. The idea behind the abolition of bearer shares was to increase corporate transparency. ${ }^{51}$ FMLC 2010, at paras. 4.6-4.8. The fact that paper-based securities are scarcely used in practice does not prevent us from stating firstly, that these types of assets are included within the scope of Art. 2(1) of the FCD and secondly, that the wording of the directive is certainly not in contrast with the idea of possession referring merely to tangibles.

52 This was expressly stated by the European Commission in the Proposal for a Directive of the European Parliament and of the Council on financial collateral arrangements /COM/2001/0168 final - COD 2001/0086 / Explanatory Memorandum, at para. 2.3.

${ }^{53}$ For example, see on this point the long-standing debate as to whether or not Article 345 TFEU (ex Article 295 EC) represents an obstacle to the development of a European property law, B. Akkermans and E. Ramaekers, "Article 345 TFEU (ex Article 295 EC), Its Meanings and Interpretations" (2010) 16 (3) European Law Journal, 292.

${ }^{54}$ Compare, for example, the Proposal for a Directive of the European Parliament and of the Council on financial collateral arrangements (COM (2001) 168 - 2001/0086 (COD) of 27 March 2001 with the Common Position (EC) No 32/2002 adopted by the Council on 5 March 2002 with a view to adopting the directive on financial collateral arrangements (2002/C $119 \mathrm{E} / 03)$ of 5 March 2002.
} 
interest over financial collaterals ${ }^{55}$. In support of this argument it is worth noting that the words 'possession/control' are mentioned in the directive using the conjunction 'or' rather than 'and' (i.e. using the expression 'possession or control' instead of 'possession and control') which confirms the intention of leaving to Member States the task of deciding which 'label' or 'form' to use when having to describe the new method of perfection set out under the $\mathrm{FCD}^{56}$.

Secondly, such an interpretation can to some extent help us overcome certain apparent inconsistencies in the EU legislation, mainly the fact that Recital 10 in the Preamble merely refers to 'some form of dispossession' omitting to mention control and that (as from the 2009 amendment to the $\mathrm{FCD}^{57}$ ) Recital 9 only makes reference to control. These inconsistencies can only be overcome by accepting the view that the expression 'possession or control' does not necessarily refer to two separate concepts and as such it needs to be interpreted as a 'composite phrase ${ }^{58}$ intended simply to reflect the different terms and concepts used by Member States through domestic legislation.

If this position were accepted, it is possible to argue that for the purpose of legal taxonomy in English law it would have been better to avoid using the concept of possession for intangibles as this can potentially lead to confusion, dictating the need for the creation of different forms of possession (depending on the nature of the collateral). Indeed, possession over tangibles is merely linked to the idea of an exclusive and absolute dominium over things which is not necessarily the only condition that the market is willing to require when perfecting a security interest over intermediated securities. On the other hand, the notion of control is designed to offer a more flexible approach that can be easily accommodated to the modern securities market, as it applies to a wider range of situations $^{59}$ (some of which draw closer to possession ${ }^{60}$ but others clearly do not ${ }^{61}$ ).

The choice of confining the notion of possession to tangibles and to documentary intangibles and to use the notion of control for intangibles seems to be more in line with the US law where it states that 'security interests in intangibles for which there is no indispensable res to be possessed (like a negotiable instrument) cannot be perfected by possession'. ${ }^{62}$ These forms of intangibles are perfected, under Articles 9 and 8 of the

\footnotetext{
55 See the European Parliament's Report on the proposal for a directive on financial collateral arrangements (COM (2001) 168 - 2001/0086 COD) of 23 November 2001. In the final version of Article 2 of the FCD the perfection requirements are described in paragraph 2 by stating that the collateral should be "delivered, transferred, held, registered or otherwise designated so as to be in the possession or under the control of the collateral taker or of a person acting on the collateral taker's behalf'. In this context, reference to 'possession or control' was added merely to clarify the exact position that the secured creditor needs to achieve on the collateral, when having the latter 'delivered, transferred, held, registered or otherwise designated'

56 The idea in favour of conferring a wider margin of discretion on Member States (when having to interpret the expression 'possession or control') is consistent with Article 288 of the Treaty on the Functioning of the EU (TFEU) which states that unlike regulations, the function of directives is to bind merely 'as to the result to be achieved', leaving 'to the national authorities the choice of forms and methods'. See also Recital 22 of the Preamble which states that the FCD introduces minimum harmonization in the area of financial collateral arrangements. Cfr. n. 92.

57 See supra n. 25.

58 The expression 'composite phrase' was coined by Beale when interpreting the meaning of 'possession or control' under the directive. See on this point H. Beale "Financial Collateral" in H. Beale and others, supra n. 1 at para. 3.38.

59 See supra text to nn. 21 and 24.

${ }^{60}$ See the combinations of (i) practical, legal, negative and positive control and (ii) practical, legal and negative control.

${ }^{61}$ See, for example, the combinations of (i) legal and positive control (ii) legal and negative control and (iii) practical positive and negative control.

62 J. J. White and R. S. Summers, supra n. 9 at 775.
} 
UCC, by way of 'control'. ${ }^{63}$ In particular, Comment 7 to $\ 8$ 8-106 UCC expressly states that ' $[\mathrm{a}]$ principal purpose of the control concept is to eliminate the uncertainty and confusion that results from attempting to apply common law possession concepts to modern securities holding practices. ${ }^{, 64}$ This confirms the idea that it would have been preferable to avoid using, under Regulation 3 (2) of the FCAR, terminology that immediately recalls common law possession concepts. However, English law has chosen to take a different path than the UCC. Hence, whatever requirements common law has imposed in defining possession, these have now been overridden by Regulation 3 (2) of the FCAR.

Notwithstanding these considerations, in the author's view the break from the traditional principles of English law (set out under Regulation 3 (2) of the FCAR) is not as radical as it appears to be on the surface. The reason for this is that firstly, the outcome of this provision confirms a general trend in English property law to respond to market needs by adapting (wherever possible) existing principles rather than creating new categories of rights. This approach has been established by courts over the centuries, by creating the idea of an equitable ownership under a trust, for example, and by extending the category of proprietary rights to include interests over an increasing number of intangibles. ${ }^{65}$ As a result of this trend, it is not at all surprising that the choice in Regulation 3 (2) of the FCAR has been to stretch the boundaries of possession rather than introducing a novel concept such as control ${ }^{66}$. Secondly, as mentioned earlier the requirements for possession set out under Regulation 3 (2) of the FCAR are quite restrictive, given that (a) the collateral should be transferred onto the creditors' account and (b) it should not be used or enjoyed by the debtor. This means that the FCAR recognises as valid methods of perfection only a very limited number of situations that may occur in practice (mainly those that can in some way embrace the traditional features of possession). In this regard, Regulation 3 (2) of the FCAR seems to accept the orthodox view, which is often stressed by English scholars, that possession 'is a question of fact as

\footnotetext{
63 Thus, as for investment securities the UCC provides two principal methods for perfecting a security interest, i.e. filing and control (\$ 9-312(a) UCC and \$9-314(a) UCC). In particular, '[a]s one might suspect, the meaning of control differs depending on whether the collateral is a certificated security, an uncertificated security, or a security entitlement. See $\$ 9-104$ (a) UCC and \$8-106 UCC. In addition, a security interest in a certificated security may be perfected by taking delivery. See $\$ 9-313$ (a) UCC and $\int 8-301$ (a) UCC. In the case of a certificated security, delivery [emphasis added] occurs when the secured party acquires possession of the security certificate $\int 8$ 8-301(a)(1) UCC', S. L. Harris and C. W. Mooney, supra n. 38 at 434435.

${ }^{64}$ Comment 7 to $\int 8-106$ UCC.

65 See on this point among others S. Worthington, "The Disappearing Divide Between Property and Obligation: The Impact of Aligning Legal Analysis and Commercial Expectation" (2006-2007) 42 Tex. Int'l L. J. 917. In support of this argument, it is worth mentioning that English law has chosen to build the legal structure of intermediation on the existing principles of trust and sub-trust, rather than introducing (along the lines of Article 8 UCC) a statutory reform in this area of law. Cfr. n. 12.

66 This flexible approach to property law opens an interesting debate as to what exactly property is today. The answer to this query cannot be summarized just in a footnote, as it requires a broader analysis (now under preparation). However, for the purpose of this article it is important to highlight the fact that (consistent with the notions of control and possession) the concept of property cannot be analysed by simply using a 'tick box' approach (as if its features were consistently applicable to all circumstances). This makes it difficult sometimes to set up clear boundaries between proprietary rights on the one hand, and contractual rights, on the other. Nowadays, the only way to distinguish property rights from contractual rights is by the fact that the former (unlike the latter) can be enforced against third parties. In support of this argument Briggs J. has recently stated that the proprietary nature of an interest depends on the intention of the parties: if the purpose was to create a right that is 'sufficiently strong' to be asserted erga omnes, then such a right can be classified as proprietary. See on this point Pearson and others $v$. Lehman Brothers Finance $S A$ [2010] EWHC 2914 (Ch), para. 225.
} 
well as of law' ${ }^{67}$ To a certain extent, the meaning of possession under Regulation 3 (2) of the FCAR may consist of two essential elements: 'first the exercise of factual [or practical] control over the [assets] ${ }^{68}$; and secondly, the 'concomitant intention to exclude others from the exercise of control ${ }^{169}$ (i.e. animus possidendi).$^{70}$ When dealing with indirectly held securities, the combination of these two elements is typically reflected in those circumstances where (i) the collateral is transferred onto the secured creditor's account and (ii) the debtor is deprived of the power to dispose of such assets, which are subsequently 'blocked' on the creditor's account, used or re-hypothecated by the creditor itself (subject, of course, to a contractual obligation to redeliver equivalent securities once the secured obligation has been performed). ${ }^{71}$ This scenario resembles the traditional meaning of possession to the extent that, as the creditor has 'exclusive control or dominium' over the assets, there is no risk of such assets being subject to competing claims. However, the FCAR goes further by also including in Regulation 3 (2) a scenario where the debtor maintains 'certain rights over the assets', i.e. the right to substitute equivalent financial collateral or to withdraw excess financial collateral.

In this particular context, the concept of possession set out under the FCAR differs slightly from its traditional meaning given that the collateral seems to have 'an identity distinct from its component parts ${ }^{72}$ and therefore the level of control granted to the secured creditor over the collateral seems to be less exclusive. Consistent with the wording of Regulation 3 (2) of the FCAR, possession is acquired over the assets that from time to time are transferred into the creditor's account rather than on the specific assets that were initially included in the collateral. ${ }^{73}$ Accordingly, provided that the overall value of the collateral remains unchanged, the 'object in possession' (i.e., the portfolio of assets that constitute such collateral) may vary from time to time, like a box whose contents change regularly.

The interpretation of the meaning of possession (offered by Regulation 3 (2) of the FCAR) is judged by most market players to be too restrictive. ${ }^{74}$ On a number of occasions, the FMLC stressed the need to introduce more substantive changes (on the

${ }^{67}$ F. Pollock and R. S. Wright, An Essay on Possession in Common Law (Clarendon Press 1888) at 10 - 20; L. C. Becker, "The Moral Basis of Property Rights" in J. R. Pennock, \& J. W. Chapman (eds.), Property, Nomos XXII (New York University Press 1980) at 190; O. W. Holmes, The Common Law, edited by M. De Wolfe Howe (Little, Brown and Company and Harvard University Press 1963) at 169; M. G. Bridge, Personal Property Law (4th edn, OUP 2015), at 33 and J. Benjamin, Financial Law, supra n. 15 at para. 16.07.

${ }^{68}$ Possession involves the physical control of the assets. As an element of 'practical' control, 'the existence of the de facto relation of control or apparent dominion [is] required as the foundation of the alleged [proprietary] right', F. Pollock and R. S. Wright, supra n. 67 at 10.

69 The expression was used by Bridge with regard to the concept of possession over tangibles. See on this point M. G. Bridge, supra n. 67 at 33. Possession has been described often as 'one of the most difficult concepts in English, or for that matter any other, law', F. H. Lawson and B. Rudden, supra n. 45 at 41 . The reason for this difficulty is that historically the concept of possession has taken many different shapes, depending on the circumstances (see among others, on this point R. Harris, "The concept of possession in English Law" in A. G. Guest Oxford Essays in Jurisprudence (OUP 1961) at 69 and F. Pollock and R. S. Wright, supra n. 67 at 1 - 10. A very clear and comprehensive analysis of possession is offered by Frederick Pollock in ibid. at 26.

${ }^{70}$ Unlike possession over tangibles, the legal element or animus possidendi set out under Regulation 3 (2) of the FCAR needs to be strictly linked to a contractual agreement between the creditor and the debtor which prevents the latter from disposing of the collateral.

${ }^{71}$ It should be borne in mind that if the securities are used or re-hypothecated by the secured creditor, the transaction is likely to be re-characterised as a repo.

${ }^{72}$ E. McKendrick, supra n. 3 at 65 . The argument was originally elaborated by Goode to explain the nature of an interest in a fund.

${ }^{73}$ Ibid.

${ }^{74}$ See on this point FMLC, Issue 1: Collateral Directive - Analysis of uncertainty regarding the meaning of "possession or control" and "excess financial collateral" under the Financial Collateral Arrangements (No. 2) Regulations 2003, December 2012 (hereafter 'FMLC 2012'), at para. 2.05 and FMLC 2015 at paras. 1 - 5. 
perfection requirements) than those introduced through the FCAR. In particular, in its Report of December 2012 the FMLC states that Article 2(2) of the FCD should not be interpreted in the sense of allowing the debtor to exercise mere rights of substitution and withdrawal of excess collateral ${ }^{75}$. The argument is confirmed by Briggs $\mathrm{J}$ in the decision of $\mathrm{Re}$ Lehman Brothers International (Europe) in Administration where he emphasises that the final sentence of Article 2(2) of the FCD is not 'a comprehensive description of the rights which may [...] reside with the [debtor], such that the enjoyment by the [debtor] of any different or wider rights would be fatal to the requirement for [perfection of a security interest]". ${ }^{76}$

The problem is to establish what other rights (apart from substitution and withdrawal of excess collateral) the debtor may be entitled to exercise. The decision in Re Lehman Brothers International (Europe) (In Administration) does not cast light on this aspect, although the general idea among practitioners seems to be in favour of allowing the debtor (i) to exercise voting right, (ii) to receive dividends or notices, (iii) to determine the value of the collateral or the secured obligations (e.g. in cases involving derivatives where the value of the obligation may fluctuate) and (iv) to obtain the return of the asset if the creditor becomes insolvent. Indeed, by doing so, there is no breach of the requirements set out under Article 2(2) of the FCD given that although the debtor is allowed to monitor and enjoy the benefits of the collateral, he/she is still prevented from actually 'disposing' of the asset. It is unfortunate that in its decision of November 2016 the CJEU does not clarify this point ${ }^{77}$.

\section{D.2 Floating charges and the unresolved debate on inclusion within the scope of the FCD}

What seems difficult to determine from the foregoing discussions is whether the security interest set out under the FCAR is to be characterised as a floating charge or as a fixed charge $e^{78}$.

\footnotetext{
${ }^{75}$ FMLC 2012, at para. 2.10 n. 4.

76 [2012] EWHC 2997 (Ch) at para. 132.

77 Private Equity Insurance Group SIA v Swedbank AS [2016] EUECJ C-156/15 (10 November 2016). The CJEU simply argues that a "right [of substitution or withdrawal] would lack any force if the taker of collateral consisting of monies deposited in an account were also to be regarded as having acquired 'possession or control' of the monies where the account holder may freely dispose of them". Of course this argument is not inconsistent with the possibility that the debtor may continue to exercise voting rights, for example, or receive dividends. Yet, a clarification on this point would have been advantageous. For a detailed analysis of the specific rights that the debtor should maintain over the collateral see FMLC, 2012, at para. 2.12 and paras. 3.1 - 3.4. See also L. Gullifer, Goode on Legal Problems of Credit, supra n. 3 at para. 6-36 and S. Goldsworthy, "Taking possession and control to excess: issues with financial collateral arrangements under English law” (2013) J.I.B.F.L. 73.

${ }^{78}$ In the United Kingdom there was clearly an attempt to bring certain floating charges within the realm of the FCAR. In particular, under Regulation 3 of the FCAR, it is stated that floating charges are included 'where the financial collateral charge is delivered, transferred, held, registered or otherwise designated so as to be in the possession or under the control of the collateral taker or a person acting on its behalf [...].' Furthermore, Regulations 8 and 10 of the FCAR are intended to disapply certain insolvency rules, which refer to floating charges and which, if applied, would restrict the enforcement of security interests in financial collateral (see s. 176 A Insolvency Act 1986; s. 245 Insolvency Act 1986; s. 754 Companies Act 2006 and para. 70, Sch. B1, Insolvency Act 1986). Despite the express reference to floating charges, the interpretation of these provisions is not very clear (as there is no precise indication of what level of possession or control must be exercised by the secured creditor in order for a floating charge to fall within the FCAR).
} 
Typically, with a floating charge the debtor is free to dispose of the charged assets in the ordinary course of business. ${ }^{79}$ This means that floating charges may potentially prevent the secured creditor from being in 'possession' of the financial assets and as a result they should be placed outside the FCAR.

However, the wording of Regulation 3 (2) of the FCAR suggests that at least some floating charges are contemplated by the provision, i.e. those which merely allow the debtor to maintain a right to substitute financial collateral of the same or greater value or to withdraw excess financial collateral. This argument is consistent with the decision of the House of Lords in Re Spectrum Plus Ltd ${ }^{80}$ which makes it clear that where the debtor is entitled to remove the collateral from the account without the consent of the secured creditor, "the charge should, in principle, be categorised as a floating charge" is that in these circumstances the secured assets "would have the circulating, ambulatory character distinctive of a floating charge" 82 and cannot be treated stricto sensu as being part of a 'blocked' account. This means that, following the decision in Re Spectrum Plus Ltd, only a total prohibition from all dealings can be considered sufficient to create a fixed charge. To put it another way, it seems that not even limited rights such as a general power to substitute or withdraw excess financial collateral (which essentially ensures that the value of the collateral remains the same) is considered enough for the purpose of a fixed charge ${ }^{83}$. This approach is in line with the view that a fixed charge has to attach to specific assets and that the secured creditor's control needs to be in some way exclusive (meaning that it has to "relate to the assets themselves and not merely to their mere value" $\left.{ }^{\prime 4}\right)$. One possible exception to this rule could be contemplated in those circumstances where the secured creditor's consent is required each time the debtor intends to undertake a transaction to substitute or withdraw excess financial collateral. The problem then is that these types of agreements are rarely used in market practice given that in most cases the secured creditor's consent is given in advance (i.e. at the moment of entering into the contract) rather than having to be granted specifically for every transaction ${ }^{85}$.

As a result of these considerations, it seems clear that the level of control (or possession) set out under the FCD is quite different from that required under English law when having to create a fixed charge.

\section{D.3 Is legal control alone sufficient to satisfy the perfection requirements?}

\footnotetext{
${ }^{79}$ A floating charge is a security interest over a pool of changing assets of the debtor, which 'floats' without attaching to any particular asset until it is 'crystallised' by attachment to specific assets. A fixed charge, by contrast, attaches to a particular asset immediately, or upon the debtor acquiring an interest in it. The effect of such an attachment is that the debtor cannot deal with the asset free from the charge and needs to obtain the chargee's permission if the asset is to be disposed of or transferred. On the test to distinguish floating charges from fixed charges see e.g. Re Atlantic Computers Ltd [1992] (Ch) 505 (CA) and Re Cosslett (Contractors) Ltd [1997] 4 All ER 115. However, the courts have experienced considerable difficulties in setting out a clear boundary between floating and fixed charges, particularly in the context of a charge over book debts. On this point, see Agnew v. IRC [2001] UKPC 28, [2001] 2 A.C. 710 and National Westminster Bank v Spectrum Plus and others [2005] UKHL 41.

80 [2005] UKHL 41.

${ }^{81}$ Ibid., para. 107.

82 Ibid. at paras. 107 and 139.

83 In support of this argument see L. Gullifer, Goode on Legal Problems of Credit, supra n. 3, at paras. 4-02 - 423; H. Beale "Non-Possessory Security" in H. Beale and others, supra n. 1, at para. 6.120 - 6.28; A. McKnight, “A review of 2010: part 2" (2011) 5 LFMR 95, at 96 - 97 and A. Zacaroli, supra n. 15, at $180-$ 182. For a different view see G. Yeowart and R. Parsons, The Law of Financial Collateral (Edward Elgar Publishing 2016), at 8.120 .

${ }^{84}$ H. Beale "Non-Possessory Security" in H. Beale and others, supra n. 1, at para. 6.127.

85 The author is grateful to Habib Motani and Emma Chell for their views on this matter.
} 
Another aspect which has been the subject of considerable attention in the United Kingdom concerns the opportunity of including within the scope of the FCAR the two combinations of (i) legal and negative control and (ii) legal, positive and negative control as valid methods of perfection.

The leading position among practitioners seems to be in favour of introducing the notion of control (in addition to the one of possession) as a means of perfection of a security interest ${ }^{86}$. In particular, the concept of control should contemplate the possibility where the collateral is on the account of the debtor, 'but on terms which give a legal right to the [secured creditor] to ensure that it is dealt with in accordance with its directions' (i.e. legal and negative control and legal, negative and positive control) ${ }^{87}$.

In the absence of a statutory clarification on this point, Briggs $\mathrm{J}$ has recently attempted to analyse the exact meaning of control and has come to the conclusion that legal control without practical control is sufficient to perfect a security interest over financial collaterals. ${ }^{88}$

The author agrees with this position but feels that Briggs' analysis does not fully explain the reasons why such an interpretation should be considered in line with the purpose of the FCD. The truth is that there is nothing really explicit in the wording of the EU legislation that could lean in favour of supporting legal control alone. However, if one looks carefully at the requirements for perfection set out (not only under Article 2(2) but also) under Recital 10 in the Preamble and under Article 1(5) one realises that such requirements can be considered satisfied when dealing with legal control alone.

Recital 10 states that the directive must provide a balance between market efficiency on the one hand and the safety of the parties in regard to the arrangement and third parties on the other. Such a balance, continues Recital 10, can only be achieved if the financial collateral arrangement provides for some form of dispossession that needs to be "evidenced in writing or in a durable medium, thereby ensuring the traceability [emphasis added] of the collateral" " The meaning of traceability is clarified in Article 1(5) of the FCD when it emphasises that "the evidencing of [dispossession] [...] must allow for the identification of the financial collateral to which it applies" "90. The objective of this provision is clearly to ensure that third parties are placed in a position which allows them to somehow locate the collateral and be aware of the existence of the security interest, hence avoiding the risk of fraud by one of the parties. Article 1(5) of the FCD goes even

\footnotetext{
86 See FMLC 2012 at para. 2.12.

87 Re Lehman Brothers International (Europe) (In Administration) [2012] EWHC 2997 (Ch) at para. 136. Once again, the CJEU does not answer this question in its decision of November 2016 (as the facts of the case relate to a rather different scenario, which simply involves cash deposited in a bank account). The only point concerning Article 2(2) of the FCD which was clarified by the CJEU is that for the purpose of 'possession or control' the secured creditor needs to be in a position to "dispose of the collateral when an enforcement event occurs" and that such an outcome can only be achieved if the debtor is actually prevented from using the collateral (Private Equity Insurance Group SLA v Swedbank AS [2016] EUECJ C156/15, paras. $41-44)$. This, however, is only confirming the idea that the creditor needs to achieve negative control, as positive control alone is not sufficient. See supra text to nn. 29 and 30.

88 Ibid. at paras. 131 - 132. Nevertheless, the combinations involving legal and negative control cannot be interpreted too restrictively, as the debtor should be entitled to exercise certain limited rights over the collateral. This means that (consistent with the interpretation proposed on the notion of possession) the debtor may be allowed, for example, to receive dividends or exercise voting rights, without this conduct preventing the secured creditor from having control over the collateral, Ibid. Similarly, the composition of the collateral portfolio can be subject to adjustment by granting the debtor the power to substitute and withdraw excess collateral, FMLC 2012 at paras. 2.9 - 3.4. Once again, in this case control is not considered jeopardised (to the extent that the secured creditor is in a position to effectively verify the debtor's activity over the collateral).

${ }^{89}$ Recital 10 in the Preamble to the FCD.

90 Art. 1(5) FCD.
} 
further by stating that "[f]or this purpose, it is sufficient to prove that the collateral has been credited to $[\ldots]$ the $[\ldots]$ account" of the secured creditor ${ }^{91}$. In other words, it is sufficient to show that the secured creditor has obtained practical and legal control. But what is exactly meant by the expression "it is sufficient"?

There are two ways of interpreting this wording.

The first possibility (which is the one preferred by the author) is based on the idea that the combination involving practical and legal control (i.e. possession) should not be regarded as the only condition for perfection but merely as a minimum standard that should be provided for under national legislation ${ }^{92}$. This means that (for the purpose of the directive) Member States are left with the discretion to choose whether or not to introduce additional methods of perfection (other than practical and legal control), provided that such methods can (i) ensure the dispossession of the collateral as described under Article 2(2) of the FCD and (ii) allow third parties to be informed about the existence of the security interest (as stated under Recital 10 in the Preamble and under Article 1(5) of the FCD). The question remains, can legal control alone satisfy such requirements? This article suggests that it is capable of doing so (despite the fact that the collateral remains credited on the debtor's account).

Legal control can be obtained either by reaching a three party contract among the intermediary, the debtor and the creditor (i.e. by way of a 'control agreement) or, alternatively, by earmarking the existence of the security interest on the debtor's account (i.e. by way of a 'designating entry'). In both cases the dispossession requirement (defined under Article 2(2) of the FCD) seems to be achieved, given that the debtor has no right to dispose of the asset (other than to substitute or withdraw excess collateral) ${ }^{93}$. On the other hand, it can be more difficult to prove the fulfilment of the notification requirement (established under Recital 10 of the Preamble and under Article 1(5) of the FCD). Indeed, when looking at the two options the most obvious reaction would be to exclude the possibility of 'tracing' or 'identifying' the collateral in the case of a control agreement. The reason for this is that a control agreement, unlike a designating entry, is a 'private matter' between the contracting parties and hence is not 'visible' on any account statement, nor to any persons authorised to review such an account. As a result, only a designating entry offers an element of transparency, i.e. the visibility of the existence of this interest within the IT system of the intermediary or within the statement account. Thus, third parties wishing to create a security interest over those assets may discover the existence of a previously created security interest when obtaining an account statement.

However, a closer look at the practice of intermediated securities shows that traceability is not necessarily linked to visibility. If the purpose of traceability is to identify the asset as it passes from one person to another (including those circumstances where the debtor grants a charge to the creditor) it is possible to argue that the same objective can be achieved by way of a control agreement (despite its lack of transparency).

Interestingly, in the United Kingdom control agreements are used by market participants more frequently than designating entries. In this case, the general view is that the intermediary (being a party to the control agreement) can disclose the existence of a security interest to third parties and by doing so, is in a position to prevent the risk of

\footnotetext{
91 Id.

92 As stated in Recital 22 of the Preamble the aim of the FCD is to "create a minimum regime relating to the use of financial collateral". This means that the directive "does not go beyond what is necessary in order to achieve that objective", $I d$. See on this point Briggs J in Re Lehman Brothers International (Europe) (In Administration) [2012] EWHC 2997 (Ch) at para. 92.

93 Of course, in these cases it is the responsibility of the debtor's own intermediary to make sure that such a condition is respected, but ultimately in the practice of intermediated securities any transaction will depend on the reliability of the intermediary.
} 
fraud by the debtor. Let us imagine, for example, that on day $1 \mathrm{X}$ grants a charge to $\mathrm{Y}$ covering all securities, credited into his/her account with D-Bank. For this purpose, on day $2 \mathrm{X}$ and $\mathrm{Y}$ conclude a control agreement under the participation of D-Bank where DBank agrees to block the securities in the account and only release them in accordance with the directions of $\mathrm{Y}$. If then on day $3 \mathrm{X}$ decides to transfer those same securities to $\mathrm{Z}$, D-Bank will be under an obligation not to proceed with such a transaction (without prior authorisation by $\mathrm{Y}$ ). Although in this case there is no visible perception of the existence of charges on the debtor's account, it is possible to argue that $\mathrm{Z}$ is deemed in any event to identify the collateral and therefore to receive 'notice'. ${ }^{94}$

In this context, it could be argued that the 'invisibility' of control agreements strengthens the dependence of third parties on the reliability of the intermediary. This is, however, considered a weak point given that (regardless of the method used in practice) third parties cannot check on the account without the authorisation of the intermediary and "account statements can be outdated within hours" bearing in mind the large number of transactions that are usually made for each account on a daily basis ${ }^{95}$.

For these reasons, it seems clear that legal control alone (obtained either by way of a control agreement or a designating entry) complies with the perfection requirements set out under the FCD. Hence, Member States may choose whether they intend to introduce within their national legislation legal control alone as a valid method of perfection (in addition to the combination involving legal and practical control).

There is, however, another way of explaining the second part of Article 1(5) of the FCD which would result in excluding legal control alone as a valid method of perfection and in considering the combination involving legal and practical control as the only alternative to registration. Such an outcome could be obtained by interpreting the FCD as stating that (for the purpose of identifying the collateral) no formal act (such as registration in a public register) is required, as it is sufficient [emphasis added] to transfer the asset on the account of the secured creditor. This interpretation, however, is not very convincing for two main reasons. Firstly, if the intention of the directive was to place legal and practical control as a condicio sine qua non for perfection, the drafting would have been more definitive and less ambiguous. Secondly (and more importantly), the European Commission has recently acknowledged the importance of recognising in cross border transactions the possibility of creating a security interest while allowing the debtor to retain the collateral in his/her account. In particular, during the negotiation process for the drafting of a new legislation on intermediated securities (Securities Law Legislation - SLL) the European Commission confirms the idea that while the combination involving legal and practical control forms the "minimum common denominator that should be generally provided for under any law" ", Member States have the option of choosing (a) whether to add legal control alone as a method of perfection and, if so (b) whether such

\footnotetext{
${ }^{94}$ A completely different outcome arises if the control agreement is reached merely between the debtor and the creditor (without the involvement of the intermediary). In this case, the existence of a charge will not be notified to third parties (other than through the information provided by the debtor). For these reasons there is a significant exposure to the risk of fraud which places these types of agreements outside the FCD (being in contrast with Recital 10 in the Preamble). The author is grateful to Habib Motani and Emma Chell for these considerations.

95 P. Paech, Cross-border issues of securities law: European efforts to support securities markets with a coherent legal framework, European Parliament's Committee on Economic and Monetary Affairs, May 2011 at para. 5.3.3. See on this point also H. Kanda and others, Official Commentary on the UNIDROIT Convention on Substantive Rules for Intermediated Securities (OUP 2012) at para. 12.30. However, one valid argument against control agreements is that an "obligation to make a designating entry [would force] the intermediary to strengthen the processes managing the various security interests it administers", ibid.

96 European Commission, Consultation Document of the Services of the Directorate- General Internal Market and Services on Legislation on Legal Certainty of Securities Holding and Dispositions, 2010, para. 4.2.
} 
a method should be achieved by way of a designating entry and/or by way of a control agreement.

The position adopted by the European Commission on legal control alone has been for the most part welcomed by the different Member States ${ }^{97}$. Yet, it has raised key issues which have not been covered by the FCD and which require urgent clarification. The most important point is to set out the criteria that determine in cases of insolvency, the order of priority among competing charges over the same assets. In other words, should priority be based on the type of method used to obtain perfection or should changes be simply ranked based on when each of them has become effective (i.e., first in time priority rule)? $?^{98}$

The absence of a clear answer on this point may have severe repercussions on the use of secured transactions and, hence, may defeat the purpose of the FCD to ensure the ready transferability of investment securities.

The working programme of the European Commission for 2016 does not include the SLL and therefore it seems likely that no further development on this project can be expected in the near future. At this point, it is to be hoped that at least the part of this project related to secured transactions will soon be introduced through either national legislation or an amendment to the FCD.

\section{D.4 Towards a statutory reform?}

The extensive and ongoing debate over the meaning of possession and control seems to be proceeding in the direction of recognising in the United Kingdom at least four different combinations of control: (i) practical, legal, negative and positive control; (ii) practical, legal and negative control; (iii) legal and negative control and (iv) legal, positive and negative control. Of these combinations the first two coincide with the new definition of possession provided by Regulation 3 (2) of the FCARs, while the last two should most likely be included in the notion of control. While Regulation 3 (2) FCAR and the decision in Re Lehman Brothers International (Europe) In Administration) have contributed to clarify the perfection requirements in financial collateral arrangements, there is still some degree of uncertainty concealed in the existing legal framework.

These considerations have recently brought the FMLC to propose an amendment of Regulation 3 (2) of the FCAR so as to allow a less restrictive interpretation of the meaning of possession over intangibles and the introduction of the concept of control (broadly along the lines of the decision in Re Lehman Brothers International (Europe) In Administration).

\footnotetext{
${ }^{97}$ See European Commission, Summary of Responses to the Directorate-General Internal Market and Services. Second Consultation. Legislation on Legal Certainty of Securities Holding and Dispositions, 2011.

98 The debate during the negotiation process focused essentially on whether the "interests in book-entry securities, which are acquired by [designating entry] have priority over interests acquired in the same bookentry by means of a control agreement [...]," Recommendation 8, Legal Certainty Group, Solutions to Legal Barriers related to Post trading within the EU, Second Advice, August 2008, 64. The main argument in favour of introducing a preferable treatment for designating entries is that "visibility" facilitates allocating positions and possibly transferring positions from a member to another in case of failures". This position, however, has been criticised by certain Member States on the basis that both methods (i.e. designating entries and control agreements) depend on the reliability of the intermediary. Hence, "if it does not comply with its book-keeping rules, the designating entry would not help" in any case, P. Paech, Cross-border issues of securities law, supra n. 94, at para. 5.3.3. As for the combination involving legal and practical control, it has been stated that "crediting and debiting are not included within the scope of the priority provisions", European Commission, Consultation Document, supra n. 95, at para. 9.2. For a critical analysis on this last point see AFME, Replies to the Consultation Document of the Services of the Directorate-General Internal Market and Services on Legislation on Legal Certainty of Securities Holding and Dispositions, December 2010, at para. 9. See also Articles 18 and 19 of the UNIDROIT Convention on substantive legal rules regarding securities held through securities accounts (Geneva, 2009).
} 
The overall intention is to strengthen the rights that the debtor may retain over the collateral as well as accommodating English law to the practice developed in other jurisdictions. ${ }^{99}$ In this regard, the HM Treasury has recently expressed its intention of giving further consideration to a possible amendment of the FCAR ${ }^{100}$ and of evaluating the FMLC's proposal to revise the meaning of possession as well as introduce the notion of control (in addition to that of possession) ${ }^{101}$.

\section{D.5. Will Brexit have an impact on the FCAR?}

To conclude section $\mathrm{D}$ of this paper, it is worth considering what effects there will be on the FCAR when the United Kingdom ceases to be a member of the European Union. Indeed, following the decision made by the British people to leave the European Union (better known as the 'Brexit decision') ${ }^{102}$, it is expected that in the near future (i.e. approximately by 2019) the United Kingdom will no longer be required to comply with EU Treaties and laws ${ }^{103}$. The decision, however, will not have an immediate impact on the FCAR which will continue to be applied, unless the United Kingdom decides to either repeal or amend such legislation. ${ }^{104}$

A decision to repeal the FCAR is quite remote, as there is a strong interest among market participants (especially among those trading derivatives) to maintain the key principles set out under the FCAR. The reason for this is that such principles play an important role in facilitating the flow of capital and providing quicker access to liquidity.

Yet, there is a possibility of certain provisions being amended, since the HM Treasury is already considering the FMLC's proposal to increase the number of exemptions to the

${ }^{99}$ See on this point FMLC 2012 at paras. 2.10.

${ }^{100}$ HM Treasury, Consultation Paper, Implementation of EU Directive 2009/44/EC on settlement finality and financial collateral arrangements, November 2010 at para. 2.21 and HM Treasury, August 2010 at paras. 3.3 3.6.

101 The FMLC was involved in discussions with the HM Treasury on the opportunity to amend Regulation 3 (2) of the FCAR. These discussions resulted in the FMLC agreeing to submit evidence on the impact that the uncertainties surrounding the FCAR may have on the wholesale financial markets. The FMCL collected evidence of such impact and in 2015 published a report that is now being evaluated by the HM Treasury. See on this point FMLC 2015.

102 On $23^{\text {rd }}$ of June 2016 the United Kingdom held a referendum on Britain's membership of the European Union. The majority of British people voted to leave the European Union. This means that when the UK Government starts the process of withdrawal (currently expected to occur in March 2017), set out under Article 50 of the Treaty on European Union ('TEU'), supposedly in approximately two years' time (starting from the beginning of the process) the United Kingdom will cease to be a member of the European Union and hence will no longer be obliged to follow EU laws.

103 The decision to leave the European Union will have the effect of repealing the European Communities Act 1972 (hereafter 'ECA'), which sets out the supremacy of EU law. For further details on this point see the Government announcement on the so-called Great Repeal Bill,

https://www.gov.uk/government/news/government-announces-end-of-european-communities-act.

104 As a general rule, EC Directives require implementation into the United Kingdom through legislation from the UK Parliament. This means that, following the entry into force of the FCAR, the principles set out under the FCD have become an integral part of national legislation. Hence, after withdrawing from the European Union, the FCAR would automatically continue to apply. A different procedure, on the other hand, should (at least in principle) be used as regards EU regulations, given that the latter are implemented directly within Member States, without the need for national legislation. In this case, EU regulations would no longer be binding in the United Kingdom and it would therefore be necessary to consider the implementation of new legislation to fill any gaps. However, in order to avoid situations of legal uncertainty, the Government has recently announced that the Great Repeal Bill, which will come into effect when the UK ceases to be a member of the EU, will contain provisions aimed at incorporating (i.e. transposing) the bulk of EU Regulations into domestic law. This will not of course prevent the UK from subsequently "review[ing] all EU related-legislation, as well as that which will be transposed by the Great Repeal Bill" and deciding whether to (i) repeal, (ii) maintain or (iii) amend each piece of such legislation. See on this point http://researchbriefings.parliament.uk/ResearchBriefing/Summary/CBP-7793. 
registration requirements. Clearly, according to exactly when the United Kingdom ceases to be a member of the European Union, then such a proposal must be evaluated without having to consider whether or not it is in line with the scope and objectives of the FCD. ${ }^{105}$ It would be completely up to the United Kingdom to decide where to strike the delicate balance between market efficiency on the one hand and safeguarding the parties from risk of fraud on the other.

\section{E. Does control or possession comply with 'publicity' requirements?}

Recent developments in the meanings of both possession and control bring us to evaluate whether such concepts are reasonably consistent with the requirement of public notice, typically associated to the perfection of a security interest.

The answer to this query is that the practice of indirectly held securities functions in a way that prevents control and possession from providing public [emphasis added] notice. The reason for this is that transfers of indirectly held securities are made in the same way as bank funds transfers and therefore, third parties have no access to the account without the authorization of the holder of that account. The next question then to be posed is, to what extent can possession or control over financial collaterals be considered valid methods of perfection of a security interest?

Article 2(2) of the FCD can be given two different interpretations. The first one is to consider this provision simply as an exception to the perfection requirements, along the lines of other cases set out in the Companies Act $2006^{106}$ and in the Banking Act $2009^{107}$. These circumstances are characterised by the fact that once the security interest is created, no further steps must be taken to ensure that such interest is effective against third parties. In other words, these types of security interest are exempted from registration simply on the grounds of policy considerations (without any effort on the part of the secured creditor). ${ }^{108}$ This interpretation, however, raises certain reservations given that (unlike the latter cases) Article 2(2) of the FCD does require the secured creditor to undertake specific actions (i.e. the transfer of control or possession) in order to avoid registration. More importantly, the objective of such actions is clearly to ensure some form of publicity, which means the disclosure of the security interest, if not to the world at large, at least to certain categories of third parties (mainly, potential subsequent secured creditors or buyers of the collateral). Hence, the correct way to explain Article 2(2) of the FCD would be to consider the transfer of control or possession (from the debtor to the creditor) as a form of perfection which does not necessarily involve the same level of publicity conceived for registration. ${ }^{109}$

\footnotetext{
105 However, it is worth mentioning that the proposal to consider legal control alone as a valid method of perfection was valued by Briggs J. in the decision of Re Lehman Brothers International (Europe) In Administration) [2012] EWHC 2997 (Ch) as being in line with the wording of the directive.

106 Sections 859A (6) (a) and (b) of the Companies Act 2006.

107 Section 252 Banking Act 2009.

108 In the United States these cases would probably be regarded as forms of 'automatic' perfection but in English law they are more likely to be considered as types of security interest that do not need to be perfected. This is emphasised by Beale when he states that the concept of perfection does not necessarily apply in the same manner in all legal systems. For example, unlike Article 9 UCC, in English law there is no general requirement of perfection, given that 'only certain types of security interest need to be perfected', H. Beale "Registration and Other Perfection Requirements" in H. Beale and others, supra n. 1, at para. 9.03. For an extensive analysis on this point see ibid, at paras. 9.03 - 9.23 and L. Gullifer, Goode on Legal Problems of Credit, supra n. 3, at paras. 2.16-2.21.

109 A different position has been set out by Bridge who views possession and control over financial collaterals as an exception to the perfection requirements, M. G. Bridge, "The Law Commission's Proposals for the Reform of Corporate Security Interests" in J. Getzler and J. Payne Company Charges: Spectrum and Beyond (OUP 2006) at 267 - 290
} 
The rationale behind this argument is that perfection is usually designed to provide some form of notice to third parties and that by third parties it is not necessarily intended the world at large but only those categories of persons which have access to financial markets. This (non-rigorous) definition of perfection is in line with Articles 9 and 8 of the UCC whose main purpose (when determining whether a notice is 'sufficient') is to ensure market efficiency, at the expense of no longer taking into consideration the interest of certain classes of persons (mainly unsecured creditors who in the absence of a registration requirement, would be unaware of the existence of a security interest). ${ }^{110}$

In this complex scenario, one could argue that for the purposes of 'perfection' different levels of notice can be provided to third parties, depending on the type of collateral involved (i.e. whether or not it is included within the scope of the FCD). The different degrees of notice may increase even further, depending on the kind of method used to actually transfer possession and control over financial collaterals. More specifically, the method stated under Regulation 3 (2) FCAR is the strongest form of notice that can be provided to third parties when perfecting a security interest over indirectly held securities. Indeed, transferring the collateral onto the creditor's account and preventing the debtor from disposing of the collateral is probably the closest one could get to the traditional meaning of 'possession'. This means that the creditor is in a position to closely monitor the assets, with the result of avoiding the risk of competing claims. ${ }^{111}$

On the other hand, when the secured creditor acquires merely legal control, the collateral remains credited in the account of the debtor and consequently, the level of notice provided to third parties is somewhat more limited than that offered under Regulation 3 (2) FCARs. This is clearly stated by Thèvenoz when he argues that with legal control alone a third party (e.g. a potential secured lender) 'has no way of assessing the existence, value and availability of the assets in the accounts other than to rely on the information disclosed by the [debtor's] intermediary'. ${ }^{112}$ In this particular case, the degree of notice may continue to vary depending on whether legal control is achieved through a designating entry or simply a control agreement. Indeed, as mentioned earlier, with a designating entry the existence of a charge is 'earmarked' on the debtor's account (and therefore is to some extent visible to third parties), while with a control agreement the disclosure of the security interest is ensured merely through the information provided by the debtor's intermediary to third parties.

In the light of these considerations, the concept of perfection needs to be partially reconsidered, as it does not seem to be constantly associated with actions that provide 'public' notice to third parties. Nowadays, the idea is that 'perfection' can provide different forms of notice, which may vary from time to time in terms of (i) number or categories of persons against whom such a notice is addressed and (ii) facility in getting access to the information concerning the security agreement. ${ }^{113}$

Once again, this position is consistent with the historical development of certain concepts of English property law. More specifically, if courts and scholars generally accept the idea that over the centuries English law has developed different levels of

\footnotetext{
110 On this point, concerns were raised by the HM Treasury which highlights the importance of balancing market efficiency on the one hand and the safety of third parties, on the other (as stated in Recital 10 in the Preamble of the FCD), HM Treasury, August 2010 at para. 3.3.

111 Of course, this would be the case only under the assumption that the intermediary acts honestly and professionally and carefully follows the instructions given by the secured party.

112 L. Thévenoz, "Intermediated Securities, Legal Risk, and the International Harmonisation of Commercial Law” (2008) 13 Stan. J. L. Bus. \& Fin. 384 at 443.

113 Such facility will depend on whether such information is located on the creditor's or on the debtor's account (and in the latter case, on whether it can be accessed through a designating entry or a control agreement).
} 
ownership (i.e. legal and equitable) and more recently even different levels of possession (depending on whether this concept entails an exclusive or non-exclusive dominium over the asset) ${ }^{114}$, there is nothing to prevent them from also recognising different levels of notice for the purpose of perfection.

The common thread among all these concepts is clearly the tendency to address market needs by softening (or maybe sometimes even blurring) the purpose and key features of well-established principles of property law.

\section{F. Conclusions}

The article centres around the four main questions raised at the beginning of our discussion, mainly (i) what is the precise meaning of control? (ii) does the FCD provide a clear definition of this new concept? (iii) what is the solution adopted in the UK (iv) does the new method of perfection (envisaged for financial collateral arrangements) offer sufficient notice to third parties?

The conclusions drawn from this analysis are that firstly there is no single or absolute definition of control, as this concept comprises at least seven different forms, whose content is liable to change depending on the intention of the parties: (i) practical, legal, negative and positive control; (ii) practical, negative and positive control; (iii) practical, legal and positive control; (iv) practical, legal and negative control; (v) legal and positive control; (vi) legal and negative control and (vii) legal, positive and negative control.

Secondly, unlike other jurisdictions, only four seem to be consistent with the scope of the FCD, i.e. (i) practical, legal, negative and positive control, (ii) practical, legal and negative control, (iii) legal and negative control and (iv) legal, positive and negative control.

Thirdly, the United Kingdom has interpreted the FCD quite restrictively, having included (under the FCAR) only the first two combinations as valid methods of perfection. In addition, it has chosen to avoid introducing the concept of control by including such combinations within the notion of possession. This solution does not seem to comply with the orthodox view that rigorously confines the concept of possession to tangibles. The resulting effect has been to create two meanings of possession, depending on the nature of the asset involved (whether tangible or intangible). More specifically, when applied to investment property, possession cannot be defined in terms of absolute or exclusive dominium over the securities, given that the portfolio of assets (forming part of the collateral) may change from time to time (provided that its overall value remains unchanged). In this regard, the definition of possession set out under Regulation 3 (2) FCAR seems to recall Roy Goode's description of an interest in a fund where such fund is considered as having 'an identity distinct from its component parts.' ${ }^{115}$

In recent years, there has been significant pressure in market practice to introduce a concept of control (in addition to the one of possession). In this regard, especially now in the aftermath of Brexit, it will be interesting to see whether the United Kingdom will decide to amend the existing legal framework and recognise new forms of exemptions from the registration requirements that are not currently contemplated by the FCAR.

Our last and fourth point concerns the need to determine whether the new idea of possession and control complies with the publicity requirements and, if not, whether it can still be considered a valid method of perfection. The analysis of the practice of indirectly held securities has shown that perfection is not necessarily designed to provide notice to the public at large (in the sense of everyone in the world) but only to those

114 See infra text to nn. 64 and 74.

115 E. McKendrick, supra n. 3 at 65. 
categories of persons who have access to this type of market. This means that there can be different degrees of notice, depending on the asset involved and the type of method chosen by the parties to perfect a security agreement.

It is apparent from this discussion that the FCD has caused the United Kingdom to stretch the boundaries of traditional principles of property law (particularly, those of possession and perfection, that can no longer be interpreted in strict or absolute terms). Nowadays, the main perception is that there can be different forms of possession as well as different forms of publicity, which may vary on each occasion, depending on the nature of the collateral and the intention of the parties. Although this approach may appear to constitute a break from certain traditional principles of law, it does confirm the view (generally recognized among academics when explaining the law of trust) that English law has developed a 'flexible' and 'malleable' idea of property ${ }^{116}$ which has proven capable of adapting to, and effectively addressing the continuing changes in market practice.

116 The terms 'flexible' and 'malleable' are used by James Penner in relation to the concept of property. On this point see Penner (1996, p. 723). 